\title{
The Covid-19's Impact on Stock Prices among Different Sectors - An Event Study Based on the Istanbul Stock Exchange Market
}

\author{
E. Asena Deniz $~^{1}{ }^{1}$ Fatih Kiliç $\oplus^{2}$ \\ Received:11.05.2021; Revised:26.06.2021; Accepted:26.06.2021
}

The Covid-19 pandemic has deeply affected our health and social life as well as the financial markets. Although the global economic effects of the coronavirus are not yet clear, it is observed that there is a reaction in the financial markets to the developments related to the pandemic. Studies show that the pandemic has strong impact on stock markets and increases uncertainty. The purpose of this study is to examine whether the stock prices of companies traded on the Istanbul Stock Exchange Market between 02.14.2019 and 04.01.2020 are affected by the Covid-19 pandemic. In this context, the stock prices of the six major sectors traded and thought to be affected in Istanbul Stock Exchange Market during the period examined were analyzed using the "event study" method of the effects of Corona virus. In the analysis, the event window was taken as $(-15,+15)$ trading days. The effects of the Corona virus in the relevant period were examined separately for each company in the selected sectors, and after calculating the abnormal returns, the effect on the average abnormal returns and cumulative abnormal returns were analyzed. According to the research results; when the general picture of selected sectors in Covid-19 is examined, statistically significant negative average cumulative abnormal returns are obtained. According to these results, Istanbul Stock Exchange has affected by Covid-19 pandemic during the period under examination.

JEL codes: F30, F37, F65

Keywords: Covid-19, Stock price response, Event study

\section{Introduction}

Covid-19, which started in China at the end of 2019 and spread all over the world, was defined as a global epidemic by the World

$1 \mathrm{PhD}$ Student at Kadir Has University, İstanbul, Turkey, email: asena.deniz@stu.khas.edu.tr

2 Master Student, Işık University, İstanbul, Turkey.
Health Organization (WHO). The global epidemic was thought to threaten human life and the health system. A virus known as the corona was enough to change the entire balance of the world. The coronavirus pandemic has caused numerous deaths globally. As of January 22, 2020, due to this epidemic the deaths have exceeded 2,16 million, which has 
continued to affect the whole world. This epidemic causes serious damage to the economic life as well as its deadly effects on public health. The pandemic is straining the health systems and economies of the most developed countries. The precautions taken due to the epidemic especially affected the economies of developing countries. Almost all of the sectors have been affected economically by Covid-19. It has adversely affected the welfare of individuals and society with the loss of income it caused. The Covid-19 outbreak seriously affects worldwide economic activities. It is expected that the epidemic will spread very rapidly all over the world, leading to a significant economic crisis in the global economy.

In this study, the impact of Covid-19 on stock prices in Turkey is examined. For this purpose, the stock prices of certain sectors traded on Istanbul Stock Exchange Market are discussed, analyzed and evaluated. The 6 sectors considered to be most affected by the Covid-19 cases are picked up. These sectors are; Transportation, Banking, Chemistry, Textile, Food and Construction. When looking at the selected sectors, it is thought that these sectors are the most economically affected, both good and bad. Because while some of the sectors such as textile, food are important because they fall into the basic needs category, some of them, have been differently affected by the results of Covid 19 .

The Covid-19's first case day was taken for analysis in Turkey. Based on the daily closing value of the stock prices of the companies traded on ISE market, the company's stock prices were analyzed with data 5 days ago and 5 days later, 10 days ago and 10 days later, 15 days earlier and 15 days after the date of Covid-19. T-test method are applied in the analysis. The reason for this is that t-test is generally included in such studies in the literature and more exact results will be obtained by statisticians when compared with other statistical analysis methods. In the literature, the most common event study method was used to measure the effect of both Covid-19 and dividend distribution announcements, stock splits or capital increases on stock prices.

\section{Literature Review}

With the World Health Organization declaring a pandemic on March 11, 2020, it became important to examine the effects of the Covid-19 virus on financial markets. The time factor plays an important role in examining the effects of a global pandemic. Also, many studies have been conducted on stock prices which are related to event study. In this part of the study, the studies on event study on stocks and the effect of Covid19 on stock prices will be discussed. This study help the new researchers to explore the Covid-19 effect on stock prices in specific sector in Istanbul Stock Exchange Market.

\subsubsection{Event Studies on Stocks}

Atkins and Dyl (1990) analyzed the behavior of stock prices after a major price change occurred during a single trading day and found evidence that the stock market overreacted, especially in price decreases. They used the average adjusted return model described by Brown and Warner (1980) and the market - adjusted risk models to measure the abnormal performance of stocks. They found that stocks (losers) that showed declining then had significant abnormal returns. They also find that stocks that show a large price increase (winning) then gain negative abnormal returns.

FAMA (1991) that the news about the use of the event study method to test whether the market is efficient or not, the fast and complete transition to the stock return is essential for efficient markets in semistrong form. For this purpose, it is inevitable not to use the event study method to measure the strength of the securities markets in semi-strong form.

KIYMAZ (1997) measured the performances of the stocks offered to the public for the first time with the event study in a study he conducted in the Manufacturing Sector of 
Istanbul Stock Exchange.

Aydogan and Muradoglu (1998) drawed to the conclusion that the announcements of dividend-priced capital increases for shares traded on the Istanbul Stock Exchange between 1988 and 1994 provide positive abnormal returns in the range of announcements between 1993 and 1994 (-30, +30 working days) in their studies examining the impact on stock prices.

Raja and Sudhahar (2010) examined the effect of capital increase by bonus issue announcements of companies in the information technologies sector in India between 2000 and 2007 on stock prices. According to the results of their research on 43 companies traded on the Bombay stock exchange; Stocks of companies in the information technology sector provide significant positive average abnormal returns on the day of the announcement of capital increase by bonus issue and the next day. Although the effect of the announcement continued for 15 days, the highest average positive abnormal return occurred on the day of the announcement.

Bekçioğlu, Öztürk, and Kaderli (2004) carried out a study that measured the effects of the established collaborations on the stocks of some companies registered to the ISE with an event study and obtained findings that the stocks reacted positively to the announcement of the event.

Worthington and Valadkhani (2004) determined to measure the effects of forty-two natural disasters in Australia on the Australian stock market by using the event study method.

Chen and Siems (2004) concluded that terrorist attacks, military actions, or unforeseen disasters are more influential in stock markets.

Atiya, Talaat, and Shaheen (n.d.) analyzed the stock price of 40 mergers and acquisitions in the United States between 1997 and 2006 with a t-test 5 day before and after the announcement date of the transaction. As a result, it shows that target firms experienced significant positive abnormal re- turns. Purchasing companies are experiencing negative abnormal returns on the day of announcement of the news of the acquisition and mergers.

ÇUKUR and ERYIĞĠT (2006) conducted another important study that measured the impact of bank mergers and acquisitions on the stock market with an event study and revealed that positive abnormal returns were obtained from stocks with the announcement of these events.

Adaoglu (2006), in his study investigating the effects of positive and negative announcements on the stock market between 1994 and 1999 in the Istanbul Stock Exchange, capital increase by bonus issue, which is interpreted as positive news in the market, during the announcement date and the following 2 working days $(0,+2)$, He stated that there was a significant positive cumulative abnormal return and a statistically insignificant negative average abnormal return was obtained in the period between the 3rd day and the 5th day. When the capital increase by bonus issue announcement was made and the 5-day period $(0,+5)$ after it, it was stated that positive cumulative abnormal return was obtained, but it was not statistically significant.

Whitworth and Rao (2010) examined the effects of the tax law changes made in the United States between 1926 and 2005 on stock returns in relation to dividend distribution. In the study, the event study method was used and 296.351 cash dividend payments in the period of 1926-2005 constituted the sample of the study.

EYÜBOĞLU and BULUT (2016) were examined by analysis using the event study method announced by the companies traded in ISE-30 for the period of January 2003December 2012. As a result of the study, it was found that investors on the day of the event were most sensitive to operational, financial and restructuring news in terms of average abnormal returns (ARR).

Sakarya and Sezgin (2015) examined the returns after the syndication loan agreement, which is predicted to affect the stock returns 
of the bank stocks traded on ISE between 01.01.2010 and 31.12.2013. As a result of this study using the event study method, they found that the announcements of banks' syndicated loan agreements in the event window $(-5,+5)$ had a positive effect (abnormal return positive) on stock returns and the market was not effective in semi-strong form.

2.0.2 Impact of Covid-19 on Stock and Stock Prices

Huynh, Lao, Sabourin, and Welte (2020), in their studies referring to the economic recession and ruins created by the Great Depression around the world, they mentioned the similar effects of viruses such as SARS and MERS originating from coronavirus. In their studies, they concluded that the number of cases of the Covid-19 pandemic has an impact on economic growth and development.

Al-Awadhi, Alsaifi, Al-Awadhi, and Alhammadi (2020) examined the effects of Covid-19 on stock exchanges with the total number of cases and deaths, stock market closing prices, stock market capitalization rate, market value / book value and daily data between 10.01.-16.03.2020. In the study conducted on Chinese stock markets, they concluded that the epidemic had a negative effect on the stock markets.

Conlon, Corbet, and McGee (2020) examined the relationship of cryptocurrencies with the Chinese stock market through GARCH modelling. The Covid-19 outbreak was included in the study as a dummy variable, and it was examined before and after. Accordingly, it was stated that a certain period of time must pass before investors will perceive new instruments such as cryptocurrencies during the period when financial channels are in crisis. At the same time, according to the results of the GARCH model, it was concluded that the epidemic had an effect on the volatility of bitcoin and gold.

GÖKER, EREN, and KARACA (2020) examined the possible impact of the COVID19 pandemic on İstanbul Stock Exchange sec- tor index returns by event analysis. According to the results of the data of 26 sectors in ISE, it was stated that most sectors achieved negative Cumulative Average Abnormal Return (CAAR) in most of the event periods investigated, while CAAR values of different sectors were positive in some periods. It was determined that the highest loss was in the Sports, Tourism and Transportation sectors. KILIÇ (2020) analyzed the impact of the COVID-19 Coronavirus pandemic on Istanbul Stock Exchange sector returns using data from January 2, 2018 to April 30, 2020. As a result of the analysis, he encountered negative abnormal returns in most of the indices. In the sector-based analysis, it was concluded that the highest negative returns were in the tourism and textile sectors, and the trade sector provided positive returns during the epidemic process.

Orhan and Tirman (2020) tried to analyze the impact of Covid-19 on fifteen sectors in Turkey with their empirical study on the ISE 100 index. In the study in which 2018-2019 comparisons were made, it was seen that the risk increased in all sectors in the first period of Covid-19, and it was determined that the losses of the sectors decreased over time. In the first period analysis, the health and pharmaceutical sector was recorded as the most profitable sector, while the clothing and textile sector was recorded as the most harmful sector.

Ekren, Alp, Erdoğan, and Güner (2021), the effects of the Covid-19 pandemic on ISE100 were examined across sectors. In addition to the number of cases in the study described as the world and the number of cases in Europe it has also been modeled in Turkey. VIX as independent variables, including CDS premiums was particularly impressed by the industry and sports industry had concluded that the number of cases in intensive markets in Turkey.

Atıcı Ustalar and Şanlısoy (2020) examined the effect of the increase in the number of Covid-19 cases on the ISE 100 returns. According to the results of the study, the num- 
ber of cases has a reducing effect on the BIST 100, but the findings that the Covid-19 outbreak alone is a shock channel for the Turkish stock market are quite weak. they have detected.

ZEREN and HIZARCI (2020) investigated whether the Covid-19 outbreak had an impact on selected Stock Exchange indices. Considering the stock market indices, Covid19 case and death numbers, unit root tests with structural break and Maki cointegration analysis were performed. Accordingly, cointegration between stock market indices and cases in selected countries has been determined. However, it has been observed that investors in Italy, Germany and France are not affected by Covid-19 cases in terms of investment behavior.

\section{Data and Methodology}

\subsubsection{Data}

When determining the sample of the study, the first announcement date of Covid19 in Turkey was taken as event date, which is March 11, 2020. In this context, 02.14.2019 - 04.01.2020, which is the period covered by the research data, 6 sectors (Transportation, Banking, Food, Textile, Chemistry and Construction) in Istanbul Stock Exchange Market are selected as the data set. The data set of the research consists of the stock prices of the companies in the sample, in Turkish Lira (TL) daily. Data got from Bloomberg.com. In this study, the case study method, which is a hybrid research technique in which finance theory and statistics science are used together, is used in many applied research in the field of economics and finance and makes it possible to measure the response of stocks to the occurrence of a selected event. In addition, in the financial economy literature, it is seen that the method of event study is heavily used in measuring the effectiveness of capital markets.

\subsubsection{Methodology}

The method of event study, also known by other names such as residual analysis and abnormal performance index, is considered an important methodological approach in experimental research based on the market in finance and accounting (Bowman, 1983). The method that is mainly used today was put forward by the researchers conducted during Ball and Brown (1968) and Fama, Fisher, Jensen, and Roll (1969) in the last years of the 1960s. Ball and Brown evaluated the information content of the earnings, while Fama, Fisher, Jensen and Roll examined the impact of their share losses after eliminating the effects of simultaneous dividend rises (Campbell, Lo, \& MacKinlay, 1997; Mazgit, 2013). In the years that have passed since these pioneering studies, many differences have been suggested in the main methodology. These differences address complications arising from the disorder of statistical assumptions used in early studies and may contain more specific hypotheses. The work of Brown and Warner $(1980,1985)$ are useful articles that discuss the practical importance of many of these differences. In the article published in 1980, application problems for sampled data were discussed for a monthly period, while daily data were used in the article in 1985 (Campbell et al., 1997).

The Event Survey method is a method commonly used in financial and economic circles to analyze the effects of announcements such as profits, mergers, acquisitions and dividends on stock prices and therefore returns of a company specific situation in general. In this method, event windows are created around this day by taking the day the announcement is made, that is, when it is first learned by the market, and it is determined whether the announcements lead to an unusual return performance in the price of the stock during these event windows. The most important elements in this method are determining the event day and event windows and measuring abnormal returns.

Defining the event date and creating the 


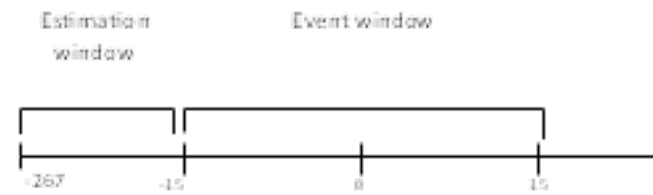

Figure 1: Event and Estimation Window

event window and prediction period (preevent window) is a critical step in the event study. The event window is created against the possibility that the information about the event is reflected in the prices and prevents the estimates from being affected by the event (Suárez, 2002). The length of the event window and estimation period varies depending on the type of event. However, generally, periods of around 200 or 250 days are preferred, which corresponds to a year before the event (Bartholdy et al., 2007). The estimation period is the period during which parameters for the model used are estimated. In this study, as observed in Figure 1, the length of the estimation window was determined to be 252 days. The event window is the period in which statistical tests are applied and inferences are made. As stated before, the first date on which the Covid-19 case was announced in Turkey will be taken as the event day in our study. Nine different event windows have been created for event windows in daily slices centered on the event day. In Table 1, descriptions of the event windows are given together with the starting and ending days. In the table, the day of the event is shown with 0 , while the days before the event day are shown with negative (-) values, while the following days are shown with positive $(+)$ values. For example, the event window with a beginning of 0 and an end of -5 corresponds to the time period five days before the event day, that is, the day when the Covid-19 case is announced in our study. Similarly, the event window with a beginning of 0 and an end of 15 includes the time period between the event day and 15 days after the event day.

The purpose of creating event windows is to evaluate the effect of the market's re-
Table 1: Event Periods

\begin{tabular}{ccl}
\hline \multicolumn{2}{c}{ Event Periods } & \\
\cline { 1 - 2 } Starting Period & Ending Period & Explanation \\
\hline-15 & 0 & Learning the situation of stock \\
-10 & 0 & prices before the Covid-19 case \\
-5 & 0 & was announced. \\
\hline 0 & 0 & Event Date \\
\hline 0 & 5 & \\
0 & 10 & Learning the effect of \\
0 & 15 & Covid-19 cases \\
5 & 5 & on stock prices. \\
-10 & 10 & \\
-15 & 15 & \\
\hline
\end{tabular}

action to the event during these windows cumulatively. Meanwhile, the effect of the event will be measured with the abnormal returns to be calculated. In this study, the length of the event window was determined as 31 days. In the study, an analysis was carried out to cover fifteen days before (-15) and 15 days after the day of the event $(+15)$.

Another important issue in the Event Study method is how to measure abnormal returns. There are different methods in the literature on this subject. In the study, the market-adjusted return model is used to calculate abnormal returns. This model is among the models defined as suitable for doing such a study in Istanbul Stock Exchange (Basdas \& Oran, 2014).

In this model, abnormal returns are calculated as;

$$
A_{i, t}=R_{i, t} R_{m, t^{*}}
$$

Where $R_{i, t}$ is the arithmetic return for security $i$ at day $t . R_{m, t^{\varsigma}}$ is the equally weighted index of the selected sectors for day $t$. A_ $\{i, t\}$ is defined as the excess return for security $i$ at day $t$. The statistical significance of the average abnormal return of event period is measured by using t-statistics.

It is important to calculate the Average Abnormal Return (AAR) and the Cumulative Abnormal Return (CAR) in the days before and after the event date. Cumulative average abnormal returns in the event window must be calculated in order to perform the test. Cumulative abnormal returns are calculated through the collection of average abnormal returns that stocks in the sample 
provide throughout the event window (Dodd \& Warner, 1983):

Average Abnormal Return - AAR

$$
A A R_{i, t}=\frac{1}{N} \sum_{i=1}^{N} A R_{i t}
$$

Cumulative Average Abnormal Return CAAR

$$
C A A R_{i, t}=\frac{1}{N} \sum_{i=1}^{N} A A R_{i t}
$$

The last step in the event study is to calculate and interpret the $\mathrm{t}$ statistics for the event day and other days in the event window. This t statistic is calculated using the following formulas (Brown \& Warner, 1980):

$$
\begin{gathered}
t=\frac{C A A R}{S\left(A A R_{t}\right)} \\
S=\sqrt{\frac{1}{252} \sum_{t=-267}^{t=-15} A A R_{t}} \\
A A R=\left(\frac{1}{252}\right) \sum_{t=-267}^{t=-15} A A R_{t}
\end{gathered}
$$

\section{Empirical Results and Discussion}

In this part of the study, the daily abnormal returns of all companies in the Transportation, Chemical, Food, Banking, Construction and Textile sectors in the Istanbul Stock Exchange Market were analyzed by the event study method in order to observe the change in stock prices with the announcement of the first Covid-19 case that emerged in Turkey on March 11, 2020. Cumulative average abnormal returns realized in the event window and Brown and Warner (1980) t-test statistics were applied.

Table ?? shows the significance test (ttest) results of the cumulative average abnormal returns in different periods within the event window. According to the test results, the average cumulative returns for the transportation sector in the periods (-15.0), $(-10.0),(-5.0),(0,+15)$ and $(-15,+15)$ are significant at the level of 0.01 and positive abnormal returns are obtained. It is significant at the 0.05 level in the period $(0,+$ $10)$ and at the level of 0.01 in the period ($5,+5)$ and negative abnormal returns are acquired. The period $(0,+5)$ is statistically insignificant. For the banking sector, the average cumulative returns for the periods ($15.0),(-10.0)$, and $(-5,+5)$ are significant at the level of 0.01 , but negative abnormal returns are obtained. However, in the periods $(0,+10),(0,+15),(-10,+10)$ and $(-$ $15,+15)$ it is significant at the level of 0.01 and positive abnormal returns are obtained. Negative abnormal returns are gotten at the level of 0.1 during the period (-5.0). The pe$\operatorname{riod}(0,+5)$ is statistically insignificant as in the transportation sector. The average cumulative returns for the chemical industry in the periods $(-15.0),(-10.0),(-5.0),(-5,+5)$ were significant at the level of 0.01 , but negative abnormal returns were achieved. Similar to the banking sector, it is significant at the level of 0.01 in the periods $(0,+10),(0,+$ $15),(-10,+10)$ and $(-15,+15)$ and positive abnormal returns are attained and $(0,+5)$ period is statistically insignificant.

In the construction industry, only the ($5,+5)$ period has negative abnormal returns at the 0.05 level, while all remaining periods are significant at the 0.01 level. The periods of $(-5,0),(-5,+5)$ and $(0,+15)$ are statistically insignificant for the Nutrient sector. $(-15,0),(-10,0)(-5,+5),(-10,+10)$ and $(-$ $15,+15)$ periods are significant at the level of 0,01 and while negative abnormal returns are obtained. In the period $(0,+10)$ negative abnormal returns at the level of 0.01 are observed. For our last sector, Textile; $(-15,0)$, $(-10,0)(-5,+5),(-10,+10)$ and $(-15,+15)$ periods are significant at the level of 0,01 and while negative abnormal returns are attained $(0,+15)$ period, negative abnormal returns are observed at 0.01 level. The remaining periods are statistically insignificant. 
Table 2: Cumulative Average Abnormal Return and t-test

\begin{tabular}{|c|c|c|c|c|c|c|}
\hline \multirow{2}{*}{$\begin{array}{l}\text { Event Date:11.03.2020 } \\
\text { Event Window }\end{array}$} & \multicolumn{2}{|c|}{ Transportation } & \multicolumn{2}{|c|}{ Banking } & \multicolumn{2}{|c|}{ Chemical } \\
\hline & CAAR & t-Test & CAAR & t-Test & CAAR & t-Test \\
\hline$(-15,0)$ & $0,078264 * * *$ & 39,663499 & $(0,039364)^{* * *}$ & $-29,76831825$ & $(0,056062)^{* * *}$ & $-28,20944907$ \\
\hline$(-10,0)$ & $0,049493^{* * *}$ & 16,721699 & $(0,043983)^{* * *}$ & $-22,17450643$ & $(0,043983)^{* * *}$ & $-22,17450643$ \\
\hline$(-5,0)$ & $0,049493 * * *$ & 16,721699 & $(0,042068)^{*}$ & $-1,696705779$ & $(0,042068)^{* * *}$ & $-1,696705779$ \\
\hline$(0,+5)$ & $-0,022929$ & $-0,619735$ & $-0,00248$ & $-0,100033383$ & $-0,00248$ & $-0,100033383$ \\
\hline$(0,+10)$ & $(0,026337)^{* * *}$ & $-8,898249$ & $0,062040 * * *$ & 31,27825644 & $0,062040 * * *$ & 31,27825644 \\
\hline$(0,+15)$ & $0,040469 * * *$ & 20,509723 & $0,066628^{* * *}$ & 50,38679058 & $0,066628 * * *$ & 50,38679058 \\
\hline$(-5,+5)$ & $(0,049552)^{* * *}$ & $-18,415628$ & $(0,055829)^{* * *}$ & $-30,96146437$ & $(0,055829)^{* * *}$ & $-30,96146437$ \\
\hline$(-10,+10)$ & $0,003263^{* *}$ & 2,315236 & $0,006776 * * *$ & 7,174027851 & $0,006777^{* * *}$ & 7,174027851 \\
\hline$(-15,+15)$ & $0,098841 * * *$ & 103,523028 & $0,015983 * * *$ & 24,98011601 & $0,015983 * * *$ & 24,98011601 \\
\hline Event Date:11.03.2020 & \multicolumn{2}{|c|}{ Construction } & \multicolumn{2}{|c|}{ Nutrient } & \multicolumn{2}{|c|}{ Textile } \\
\hline Event Window & CAAR & t-Test & CAAR & t-Test & CAAR & $\mathrm{t}$-Test \\
\hline$(-15,0)$ & $(0,085782)^{* * *}$ & $-42,90007752$ & $(0,029546)^{* * *}$ & $-14,97619905$ & $(0,051280)^{* * *}$ & $-17,35002248$ \\
\hline$(-10,0)$ & $(0,078208)^{* * *}$ & $-26,07473678$ & $(0,041983)^{* * *}$ & $-14,18679596$ & $(0,019372)^{* * *}$ & $-4,36949035$ \\
\hline$(-5,0)$ & $(0,078124)^{* *}$ & $-2,083749178$ & $-0,038501$ & $-1,040828517$ & $-0,037998$ & $-0,685666245$ \\
\hline$(0,+5)$ & $(0,169629)^{* * *}$ & $-4,524390644$ & $-0,030740$ & $-0,831024887$ & $-0,080572$ & $-1,453889301$ \\
\hline$(0,+10)$ & $(0,136852)^{* * *}$ & $-45,62684081$ & $0,021944 * * *$ & 7,415475646 & $-0,001800$ & $-0,405961644$ \\
\hline$(0,+15)$ & $(0,043412)^{* * *}$ & $-21,71048456$ & 0,000113 & 0,057255753 & $0,055476 * * *$ & 18,76947483 \\
\hline$(-5,+5)$ & $(0,263331)^{* * *}$ & $-96,5751319$ & $(0,082623)^{* * *}$ & $-30,71205978$ & $(0,130201)^{* * *}$ & $-32,3046981$ \\
\hline$(-10,+10)$ & $(0,230637)^{* * *}$ & $-161,480349$ & $(0,033420)^{* * *}$ & $-23,71573495$ & $(0,032803)^{* * *}$ & $-15,53772158$ \\
\hline$(-15,+15)$ & $(0,144772)^{* * *}$ & $-149,6293577$ & $(0,042814)^{* * *}$ & $-44,8503319$ & $(0,007436)^{* * *}$ & $-5,199200582$ \\
\hline \multicolumn{7}{|c|}{$\begin{array}{l}\text { CAAR stands for cumulative abnormal return. The ordinate represents the event window. }{ }^{* * *},{ }^{* *} \text {, and }{ }^{*} \text { are significant at } 1 \%, 5 \%, \text { and } 10 \% \\
\text { confidence levels, respectively. }\end{array}$} \\
\hline \multicolumn{7}{|c|}{${ }^{*} p<0.10, * * p<0.05 . * * * p<0.01$. t-tests are based on Brown and Warner (1985). } \\
\hline \multicolumn{7}{|c|}{$\% 99$ confidence level( $\% 1$ significance level) $=2,576$} \\
\hline \multicolumn{7}{|c|}{$\% 95$ confidence level( $\% 5$ significance level $)=1,96$} \\
\hline$\% 90$ confidence level $(\% 1$ & 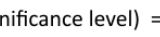 & & & & & \\
\hline
\end{tabular}

\section{Conclusion}

The Covid-19 pandemic has created significant uncertainties for companies, policymakers and investors due to the damage caused and likely to be caused. These uncertainties have affected the world financial markets deeply and with a certain volatility. Financial markets in Turkey, like other developed and emerging markets, have been significantly affected. This study demonstrates the effects of the Covid-19 pandemic. According to the results, the stock market gives statistically significant responses to the case news. The market mostly reacts negatively in the periods before and after the date the first case is announced.

When the changes in the number of cases are examined, it has been determined that the market responses can also differ from for each sector. In general, the construction and textile sector, especially is more affected than other sectors examined by the pandemicrelated financial fluctuation before and after the case day announced in Turkey. While the chemical industry is affected as negative before the event date, it is affected as positive after the event date according to the expected estimates. This positive effect may be due to the increasing need for cargo bags due to the increase in online shopping.

Banking, Transport and Food sectors are affected both positively and negatively. The transportation sector is expected to be affected as negative by the bans that come with increasing case numbers worldwide. The Food and Banking sector is thought to be so affected by the first-time people have encountered the pandemic.

It is aimed that the examples of market studies on the impact of the pandemic on sectoral-based financial markets are limited and this study, which provides detailed evidence in Turkey, will guide the next studies. It is thought that sectoral examination of the pandemic-related case effect will guide firms and investors in the measures they will take in future periods. Some of sectors could not be analyzed because the sectors that were thought to be more affected were analyzed. The first case that occurs in China can be observed by including it as the day of the event 
and changing the event windows so that the sample will cause different changes.

\section{References}

Adaoglu, C. (2006, jul). Market reaction to "unsweetened" and "sweetened" rights offerings in an emerging european stock market. Journal of Multinational Financial Management, 16(3), 249-268. Retrieved from https:// doi.org/10.1016\%2Fj.mulfin. 2005.07.001 doi:10.1016/j.mulfin.2005.07.001

Al-Awadhi, A. M., Alsaifi, K., Al-Awadhi, A., \& Alhammadi, S. (2020, sep). Death and contagious infectious diseases: Impact of the COVID-19 virus on stock market returns. Journal of Behavioral and Experimental Finance, 27, 100326. Retrieved from https://doi.org/10.1016\%2Fj.jbef. 2020 .100326 doi:10.1016/j.jbef.2020.100326

Atıcı Ustalar, S., \& Şanlısoy, S. (2020). Covid-19 küresel salgınının bïst100 getirisi üzerine etkisinin analizi. Ahmet Yesevi Üniversitesi Yayınları.

Atiya, A., Talaat, N., \& Shaheen, S. (n.d.). An efficient stock market forecasting model using neural networks. In Proceedings of international conference on neural networks (ICNN'97). IEEE. Retrieved from https://doi.org/10.1109\%2Ficnn .1997 .614231 doi:10.1109/icnn.1997.614231

Atkins, A. B., \& Dyl, E. A. (1990, dec). Price reversals, bid-ask spreads, and market efficiency. The Journal of Financial and Quantitative Analysis, 25(4), 535. Retrieved from https://doi.org/ 10.2307\%2F 2331015 doi: $10.2307 / 2331015$

Aydogan, K., \& Muradoglu, G. (1998, feb). Do markets learn from experience? price reaction to stock dividends in the turkish market. Applied Financial Economics, 8(1), 41-49. Retrieved from https://doi.org/10.1080\%2F096031098333230 doi:10.1080/096031098333230

Ball, R., \& Brown, P. (1968). An empirical evaluation of accounting income numbers. Journal of Accounting Research, 6(2), 159. Retrieved from https://doi.org/10.2307\% 2F2490232 doi:10.2307/2490232

Bartholdy, J., Olson, D., \& Peare, P. (2007, apr). Conducting event studies on a small stock exchange. The European Journal of Finance, 13(3), 227-252. Retrieved from https:// doi.org/10.1080\%2F13518470600880176 doi:10.1080/13518470600880176

Basdas, U., \& Oran, A. (2014, sep). Event studies in turkey. Borsa Istanbul Review, 14(3), 167-188. Retrieved from https:// doi.org/10.1016\%2Fj.bir. 2014.03.003 doi:10.1016/j.bir.2014.03.003

Bekçioğlu, S., Öztürk, M., \& Kaderli, Y. (2004). Kurulan işbirliklerinin imkb'ye kayıtlı izocam, çelebi ve netaş firmalarının hisse senetleri üzerindeki etkisinin ölçülmesi: Bir olay etüdü denemesi. Muhasebe ve Finansman Dergisi, 21, 43-
48.

Bowman, R. G. (1983, dec). UNDERSTANDING AND CONDUCTING EVENT STUDIES. Journal of Business Finance \& Accounting, 10(4), 561-584. Retrieved from https://doi.org/ 10.1111\%2Fj.1468-5957.1983.tb00453.x doi:10.1111/j.1468-5957.1983.tb00453.x

Brown, S. J., \& Warner, J. B. (1980, sep). Measuring security price performance. Journal of Financial Economics, 8(3), 205-258. Retrieved from https://doi.org/10.1016\%2F0304 $-405 \mathrm{x} \% 2880 \% 2990002-1 \quad$ doi:10.1016/0304$405 x(80) 90002-1$

Brown, S. J., \& Warner, J. B. (1985, mar). Using daily stock returns. Journal of Financial Economics, 14(1), 3-31. Retrieved from https:// doi . org/10.1016\%2F0304-405x\%2885\%2990042-x doi:10.1016/0304-405x(85)90042-x

Campbell, J. Y., Lo, A. W., \& MacKinlay, A. C. (1997). The econometrics of financial markets. Princeton University Press. Retrieved from https://doi.org/10.1515\%2F9781400830213 doi:10.1515/9781400830213

Chen, A. H., \& Siems, T. F. (2004, jun). The effects of terrorism on global capital markets. European Journal of Political Economy, 20(2), 349-366. Retrieved from https:// doi.org/10.1016\%2Fj.ejpoleco.2003.12.005 doi:10.1016/j.ejpoleco.2003.12.005

Conlon, T., Corbet, S., \& McGee, R. (2020). Are cryptocurrencies a safe haven for equity markets? an international perspective from the COVID-19 pandemic. SSRN Electronic Journal. Retrieved from https://doi.org/10.2139\%2Fssrn. 3601045 doi:10.2139/ssrn.3601045

ÇUKUR, S., \& ERYİĞİT, R. (2006, jun). Banka birleşme ve devralma olaylarının borsadaki etkisi. İktisat Issletme ve Finans, 21(243). Retrieved from https://doi.org/10.3848\%2Fiif. 2006.243 .9464 doi:10.3848/iif.2006.243.9464

Dodd, P., \& Warner, J. B. (1983, apr). On corporate governance. Journal of $\mathrm{Fi}$ nancial Economics, 11(1-4), 401-438. Retrieved from https://doi.org/10.1016\%2F0304 $-405 \times \% 2883 \% 2990018-1 \quad$ doi:10.1016/0304$405 \times(83) 90018-1$

Ekren, N., Alp, E. A., Erdoğan, M. F., \& Güner, Y. (2021). The impact of covid-19 on the firms: Results of the thematic survey conducted by cscpa of istanbul. International Journal of Commerce and Finance, 7(1), 166-180.

EYÜBOĞLU, K., \& BULUT, H. İ. (2016). ŞiRKETLERE ÖZGÜ HABERLERin hïSSE PERFORMANSINA ETKisi: BiST-30 şiRKETLERi ÖRNEği. Uluslararası İktisadi ve İdari Incelemeler Dergisi, O(16). Retrieved from https://doi.org/10.18092\%2Fijeas. 96170 doi:10.18092/ijeas.96170

FAMA, E. F. (1991, dec). Efficient capital markets: II. The Journal of Finance, 46(5), 1575-1617. Retrieved from https://doi.org/ 10.1111\%2Fj.1540-6261.1991.tb04636.x doi:10.1111/j.1540-6261.1991.tb04636.x 
Fama, E. F., Fisher, L., Jensen, M. C., \& Roll, R. (1969, feb). The adjustment of stock prices to new information. International Economic Review, 10(1), 1. Retrieved from https://doi.org/ 10.2307\%2F2525569 doi: $10.2307 / 2525569$

GÖKER, İ. E. K., EREN, B. S., \& KARACA, S. S. (2020, jun). COVID-19 (koronavirüs)'un borsa istanbul sektör endeks getirileri Üzerindeki etkisi: Bir olay çalışması. Gaziantep University Journal of Social Sciences. Retrieved from https://doi.org/10.21547\%2Fjss.731980 doi: $10.21547 /$ jss. 731980

Huynh, K., Lao, H., Sabourin, P., \& Welte, A. (2020). What do high-frequency expenditure network data reveal about spending and inflation during covid19? (Tech. Rep.). Bank of Canada.

KILIÇ, Y. (2020). Borsa istanbul'da covid-19 (koronavirüs) etkisi. JOEEP: Journal of Emerging Economies and Policy, 5(1), 66-77.

KIYMAZ, H. (1997, may). İmkb"de 1996 yılında halka arzedilen hisse senetlerinin performanslari. Íktisat İsletme ve Finans, 12(134). Retrieved from https://doi.org/10.3848\%2Fiif.1997.134 .9096 doi:10.3848/iif.1997.134.9096

Mazgit, İ. (2013). Endeks kapsamında olmanın hisse senedi getirilerine etkisi: Bist temettü 25 endeksi üzerine bir uygulama. Sosyoekonomi, 20(20).

Orhan, Z. H., \& Tirman, N. (2020, sep). Analysis of the impact of covid-19 on different sectors in turkey during early periods of the pandemic. Journal of Business Research - Turk, 12(3), 2312-2326. Retrieved from https:// doi.org/10.20491\%2Fisarder. 2020.978 doi:10.20491/isarder.2020.978

Raja, M., \& Sudhahar, J. C. (2010). An empirical test of indian stock market efficiency in respect of bonus announcement. Asia Pacific Journal of Finance 83 Banking Research, 4(4).

Sakarya, Ş., \& Sezgin, H. (2015). Sendikasyon kredisi kullanımının bankaların hisse senedi getirilerine etkisi: Olay çalışması yöntemiyle bist'de bir uygulama.

Suárez, M. M. V. (2002, dec). Stock market response to the formation of global alliances: evidence from spanish corporations. European Business Review, 14(6), 401-408. Retrieved from https:// doi.org/10.1108\%2F09555340210448758 doi:10.1108/09555340210448758

Whitworth, J., \& Rao, R. P. (2010, mar). Do tax law changes influence ex-dividend stock price behavior? evidence from 1926 to 2005. Financial Management, 39(1), 419-445. Retrieved from https://doi.org/10.1111\%2Fj .1755-053x.2010.01078.x doi:10.1111/j.1755053x.2010.01078.x

Worthington, A., \& Valadkhani, A. (2004, oct). Measuring the impact of natural disasters on capital markets: an empirical application using intervention analysis. Applied Economics, 36(19), 2177-2186. Retrieved from https:// doi.org/10.1080\%2F0003684042000282489 doi:10.1080/0003684042000282489

ZEREN, F., \& HIZARCI, A. (2020, apr). THE
IMPACT OF COVID-19 CORONAVIRUS ON STOCK MARKETS: EVIDENCE FROM SELECTED COUNTRIES. Muhasebe ve Finans Incelemeleri Dergisi. Retrieved from https://doi.org/10.32951\%2Fmufider.706159 doi:10.32951/mufider.706159 